\title{
Errata
}

\section{The Publisher}

An erratum is issued to the articles mentioned below because of incorrect Copyright Line. It should read "Springer Science + Business Media, LLC" instead of "Springer Science + Business Media B.V."

\section{Robust human development rankings}

\section{Laurens Cherchye · Erwin Ooghe · Tom Van Puyenbroeck}

Received: 23 January 2006 / Accepted: 23 March 2007

(C) Springer Science + Business Media, LLC 2007

\section{Erratum to: Journal of Economic Inequality DOI 10.1007/s10888-007-9058-8}

Biases of the ordinary least squares and instrumental variables estimators of the intergenerational earnings elasticity: Revisited in the light of panel data

\section{Ramses H. Abul Naga}

Received: 1 February 2007 / Accepted: 7 August 2007

(C) Springer Science + Business Media, LLC 2007

\section{Erratum to: Journal of Economic Inequality}

DOI 10.1007/s10888-007-9065-9

The online versions of the original articles can be found under doi: 10.1007/s10888-007-9058-8 and doi: 10.1007/s10888-007-9065-9. 